\title{
Lipid-Raft-Mediated Direct Cytosolic Delivery of Polymer-Coated Soft Nanoparticles
}

Prasanta Panja and Nikhil R. Jana*

School of Materials Science, Indian Association for the Cultivation of Science, Jadavpur, Kolkata-700032, India

*Corresponding author E-mail: camnrj@iacs.res.in

Table S1. Property of nanoparticles in serum free and serum containing cell culture media.

\begin{tabular}{lcccc} 
Abbreviation & \multicolumn{2}{c}{ Average DLS size $(\mathrm{nm})$} & \multicolumn{2}{c}{ Zeta Potential $(\mathrm{mV})$} \\
$\begin{array}{c}\text { Serum containing } \\
\text { media }\end{array}$ & Serum free media & $\begin{array}{c}\text { Serum containing } \\
\text { media }\end{array}$ & Serum free media \\
QD 40-I & 43 & 39 & +5 & +8 \\
QD 40-II & 45 & 47 & -7 & -5 \\
QD 40-III & 44 & 50 & -1 & -2
\end{tabular}



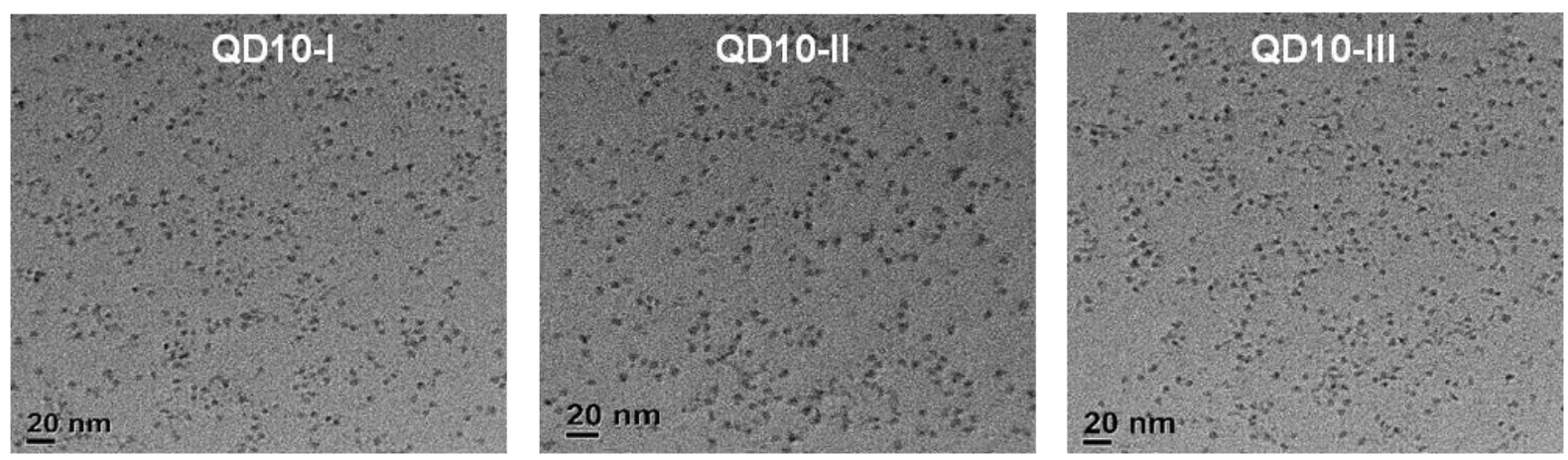

Figure S1. TEM image of QD10-I, QD10-II and QD10-III showing only the core QD.

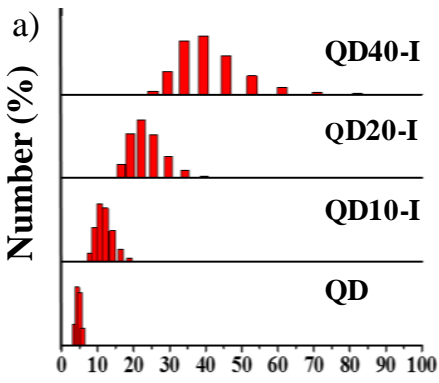

Size (nm)

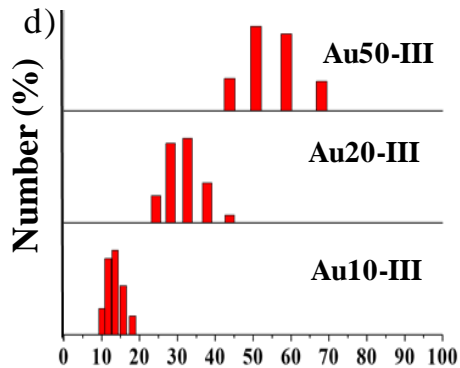

Size $(\mathbf{n m})$

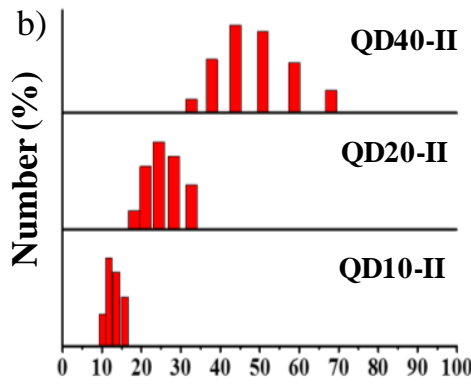

Size (nm)

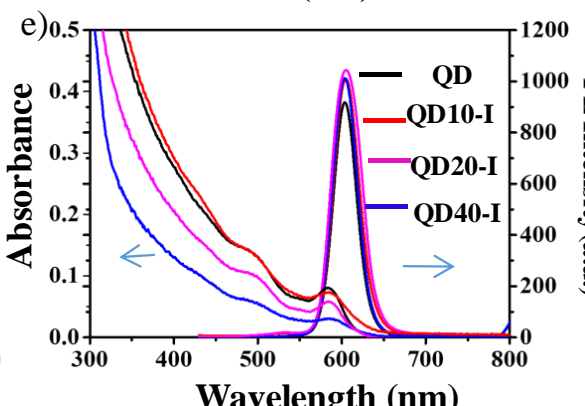

Wavelength (nm)

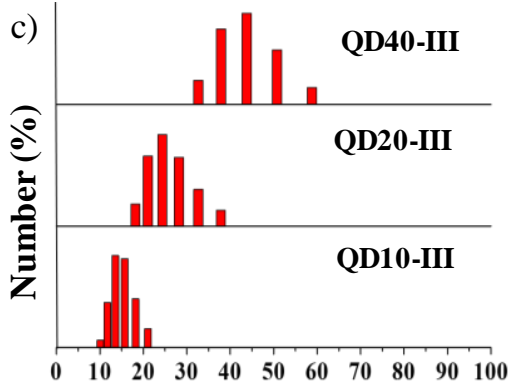

Size(nm)

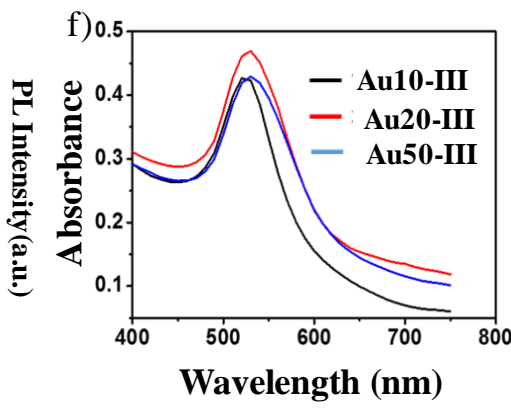

Figure S2. Hydrodynamic size of QD/Au nanoparticles (a-d), UV-visible absorption and fluorescence property of QD samples (e) and UV-visible absorption spectra of Au nanoparticles (f). 


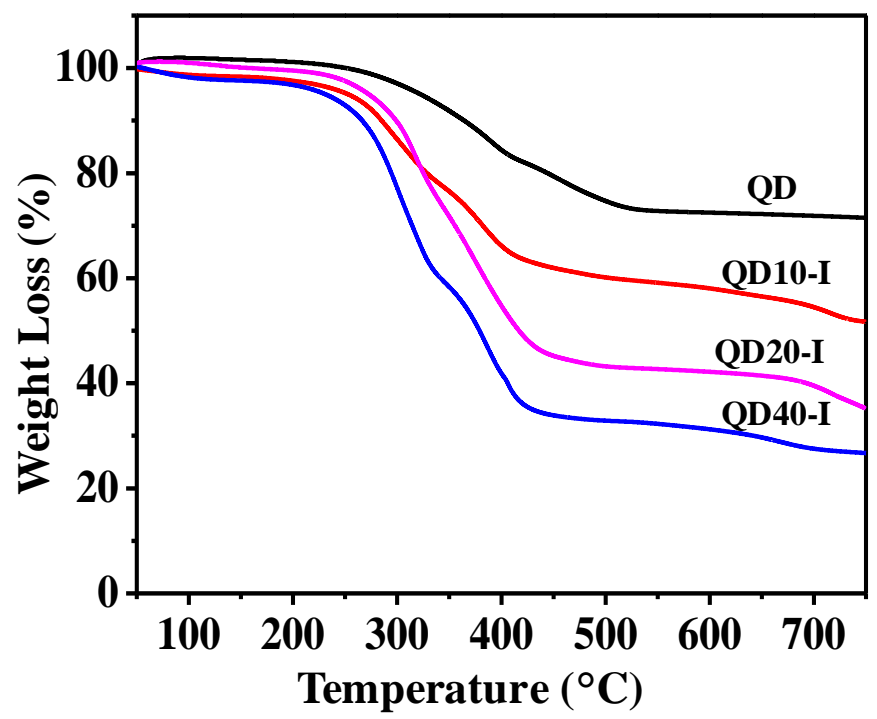

\begin{tabular}{|c|c|}
\hline Sample & Weight Loss (\%) \\
\hline QD & 26 \\
\hline QD10-I & 38 \\
\hline QD20-I & 55 \\
\hline QD40-I & 65 \\
\hline
\end{tabular}

Figure S3. Thermogravimetric analysis of QD10-I/QD20-I/QD40-I showing the increased loss of $\%$ wt due to increased polymer $\%$ that are reflected in increased hydrodynamic size. QD represents hydrophobic QD.

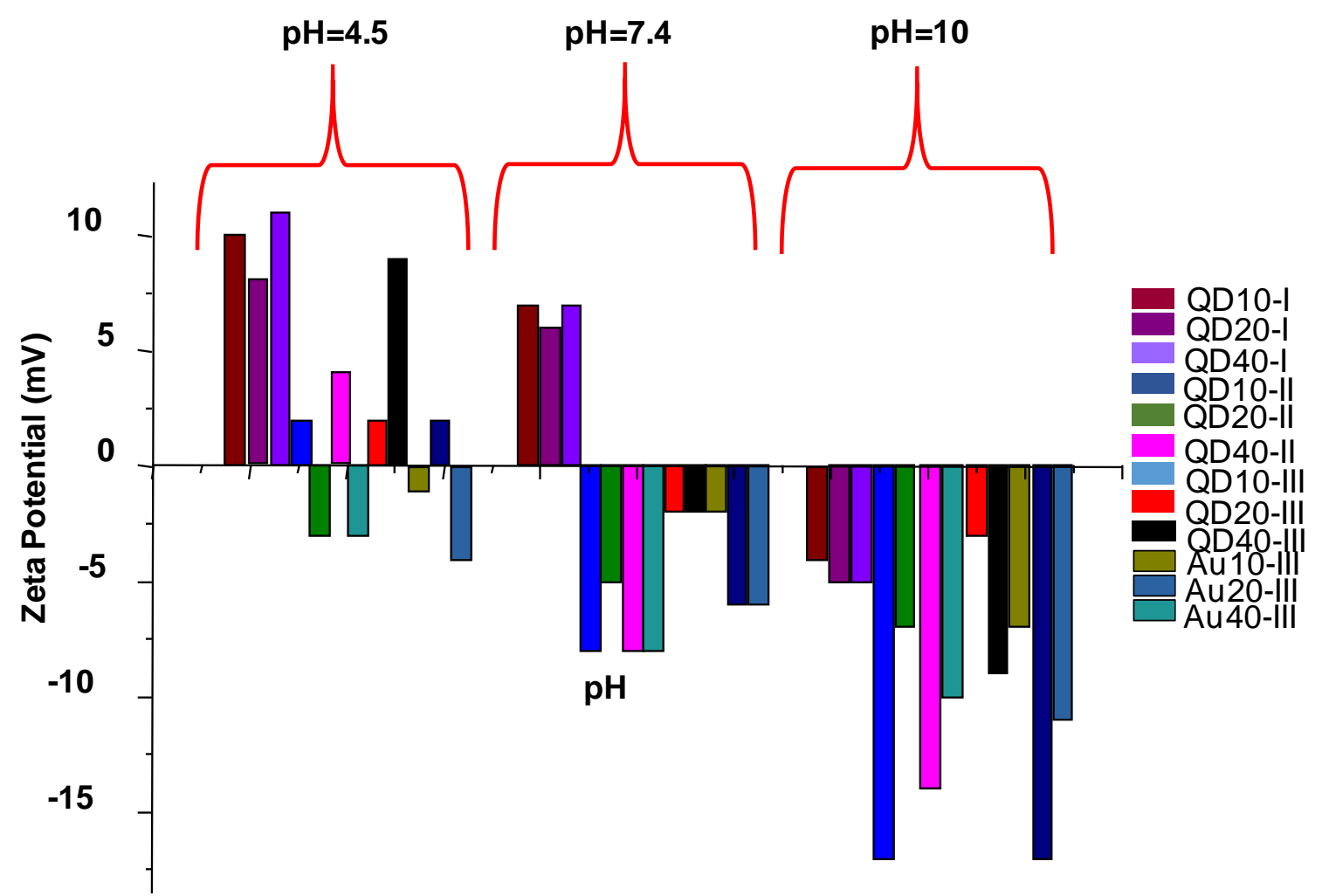

Figure S4. Zeta potential of colloidal nanoparticles at different solution $\mathrm{pH}$ that are used in this study. 

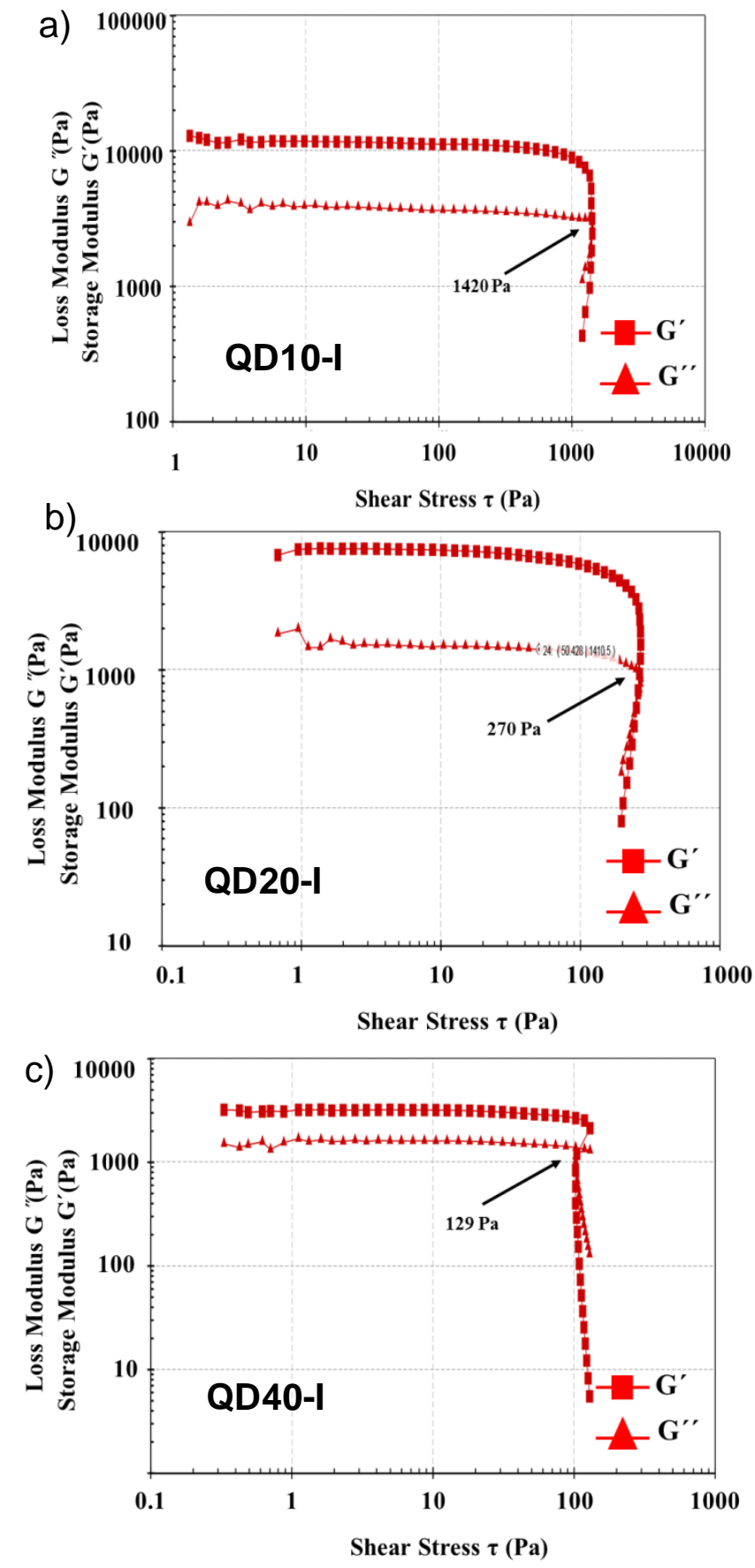

Figure S5. The rheological data of thin film of QD10-I(a)/QD20-I(b)/QD40-I(c) showing that increased polymeric shell thickness increases softness of nanoparticle. Thin film of nanoparticles are used for measurement of the dynamic stress sweep in the range of 0-10000 Pa for measuring dynamic storage modulus or elastic modulus $\left(\mathrm{G}^{\prime}\right)$, loss modulus or viscosity modulus $\left(G^{\prime \prime}\right)$ and yield stress. Greater magnitude of $G^{\prime}$ than $G^{\prime \prime}$ and decreased yield stress with increasing shell thickness indicate gel like structure. Yield stress was determined to be $1420 \mathrm{~Pa}$ for the QD10-I, $270 \mathrm{~Pa}$ for QD20-I and $129 \mathrm{~Pa}$ for the QD40-I. 

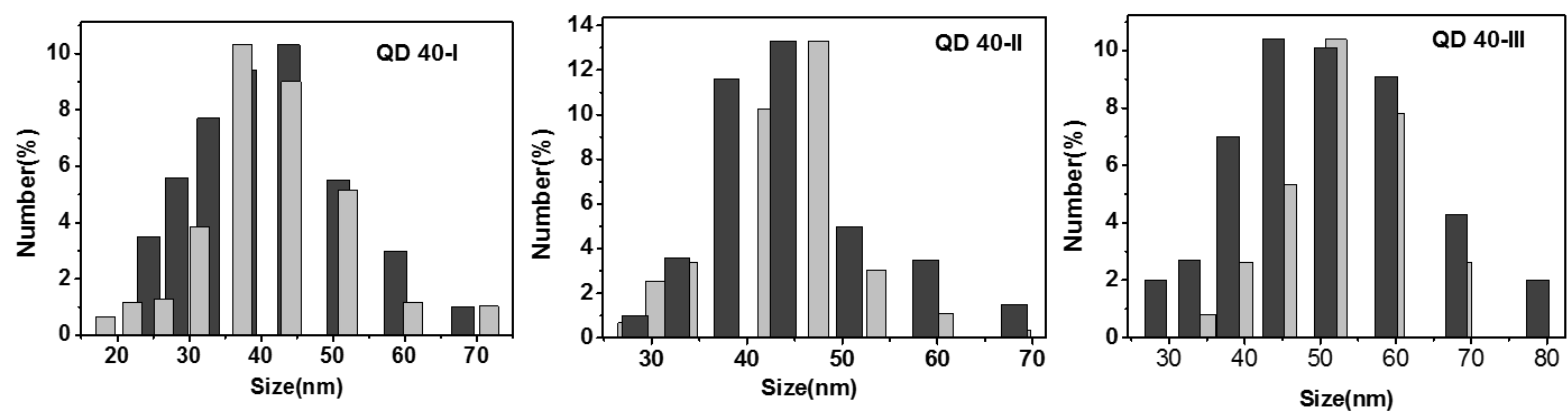

Serum containing media

Serum free media

Figure S6. Hydrodynamic size of QD40-I, QD40-II, QD40-III in serum free cell culture media (light grey bars) and serum containing cell culture media (dark grey bars) as observed by dynamic light scattering study. Results show insignificant change in their hydrodynamic size.
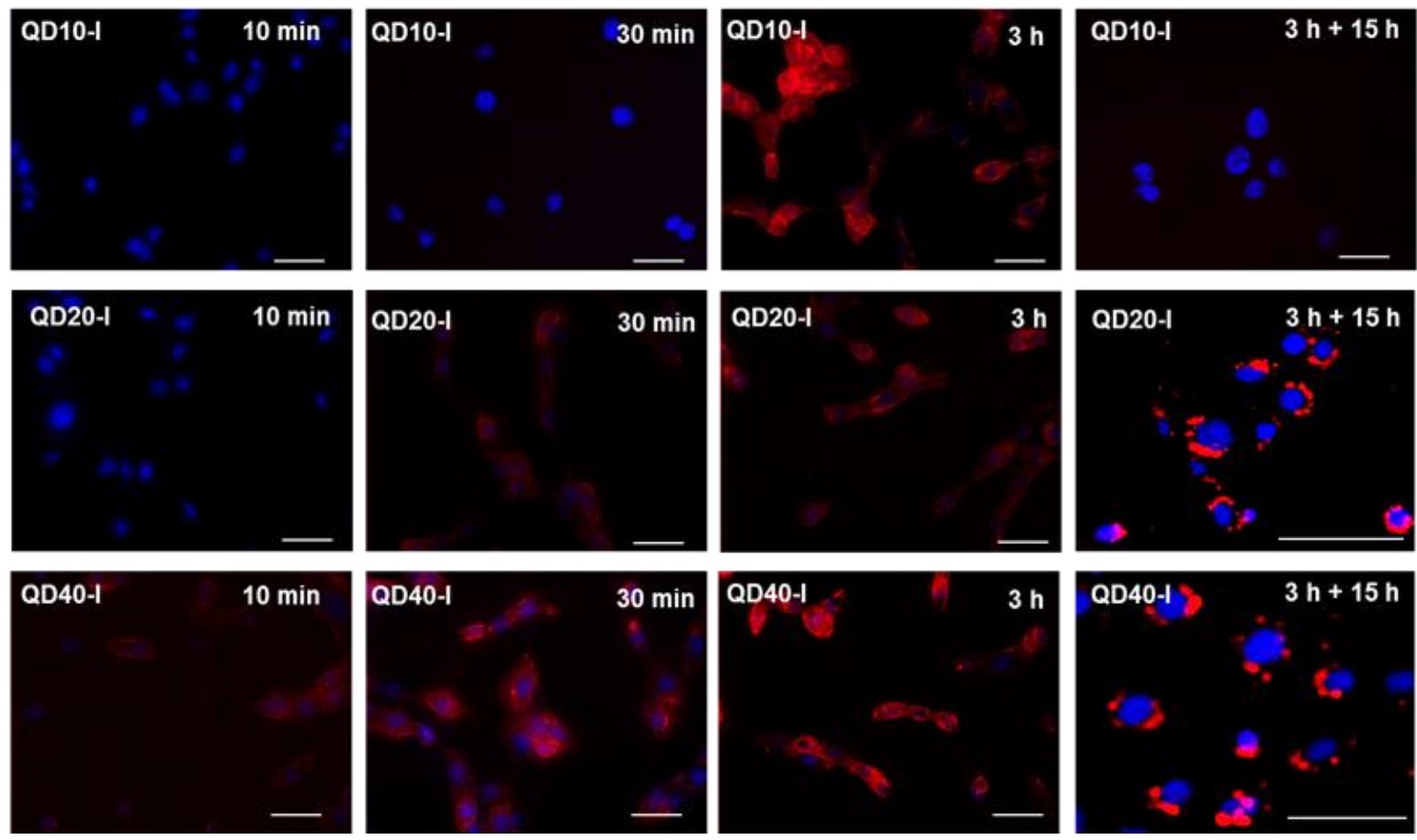

Figure S7. Enhanced cellular interaction and cell uptake of QD10-I/QD20-I/QD40-I with increased shell thickness and hydrodynamic size. Typically, HT22 cells are incubated with nanoparticle for $10 \mathrm{~min} / 30 \mathrm{~min} / 3 \mathrm{~h} / 3 \mathrm{~h}$ followed by $15 \mathrm{~h}$ incubation in fresh media. Finally, cells are incubated with nuclear probe and washed cells are used for imaging study. Scale bar represents $50 \mu \mathrm{m}$. 

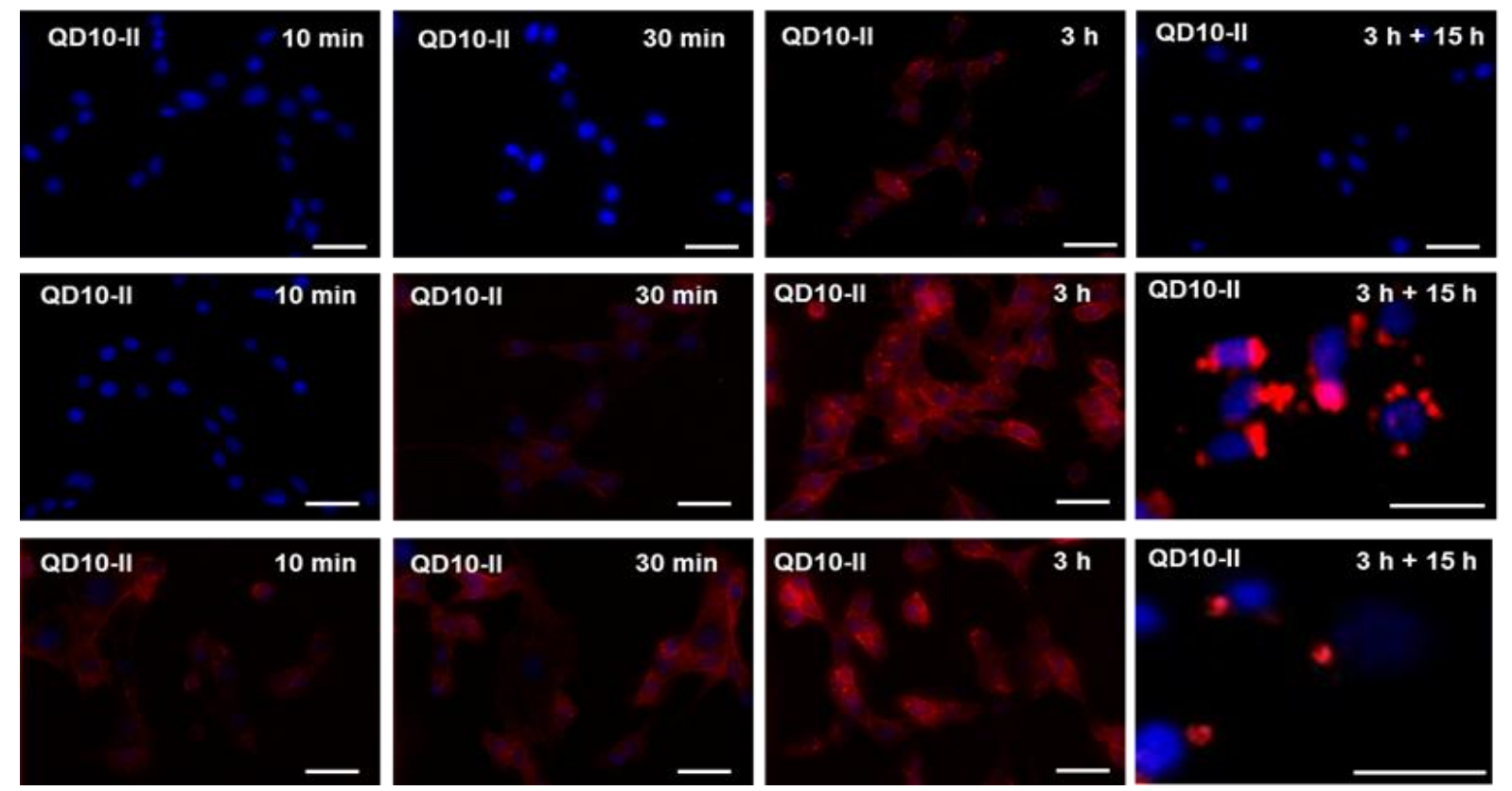

Figure S8. Enhanced cellular interaction and cell uptake of QD10-II/QD20-II/QD40-II with increased shell thickness and hydrodynamic size. Typically, HT22 cells are incubated with nanoparticle for $10 \mathrm{~min} / 30 \mathrm{~min} / 3 \mathrm{~h} / 3 \mathrm{~h}$ followed by $15 \mathrm{~h}$ incubation in fresh media. Finally, cells are incubated with nuclear probe and washed cells are used for imaging study. Scale bar represents $50 \mu \mathrm{m}$. 

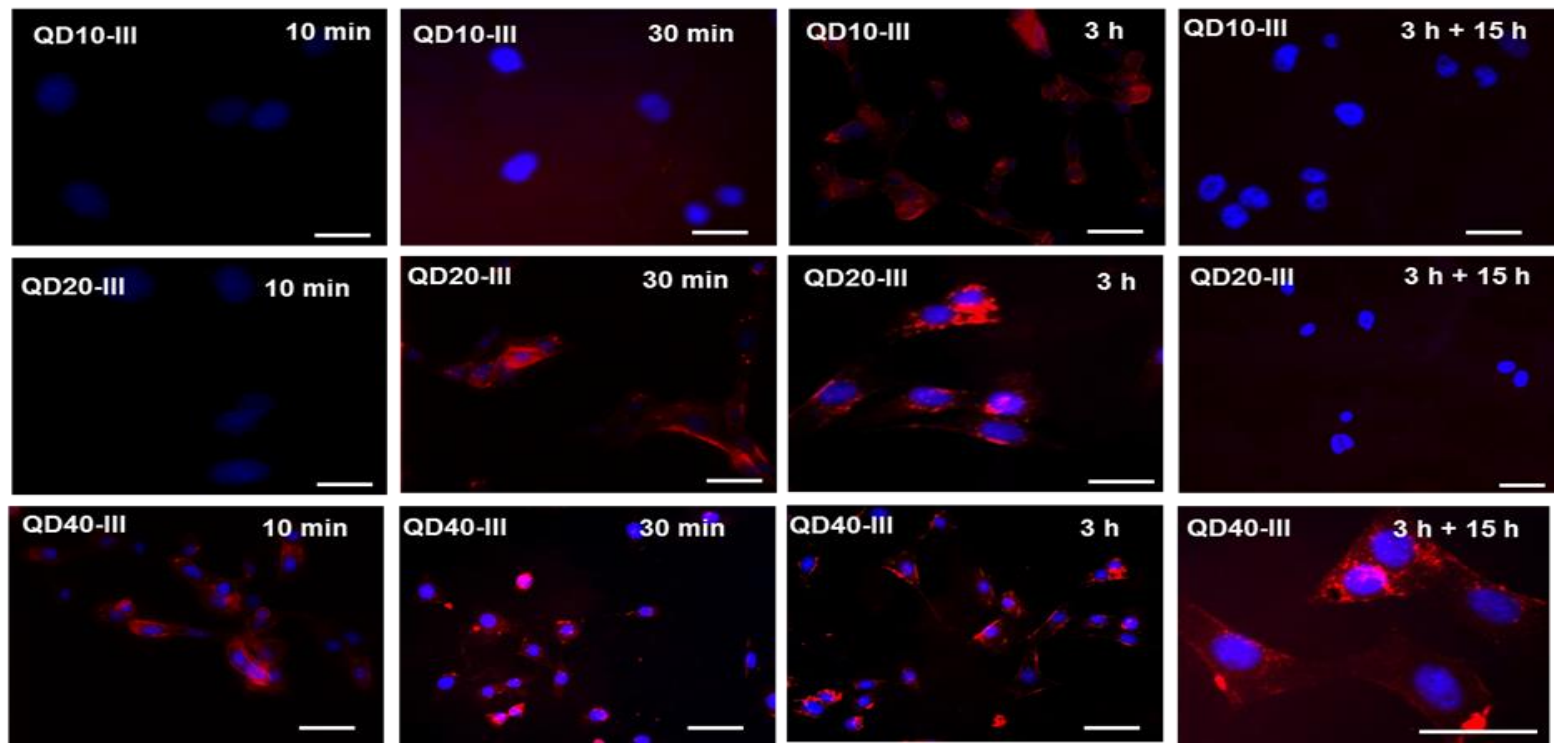

Figure S9. Enhanced cellular interaction and cell uptake of QD10-III/QD20-III/QD40-III with increased shell thickness and hydrodynamic size. Typically, HT22 cells are incubated with nanoparticle for $10 \mathrm{~min} / 30 \mathrm{~min} / 3 \mathrm{~h} / 3 \mathrm{~h}$ followed by $15 \mathrm{~h}$ incubation in fresh media. Finally, cells are incubated with nuclear probe and washed cells are used for imaging study. Scale bar represents $50 \mu \mathrm{m}$. 


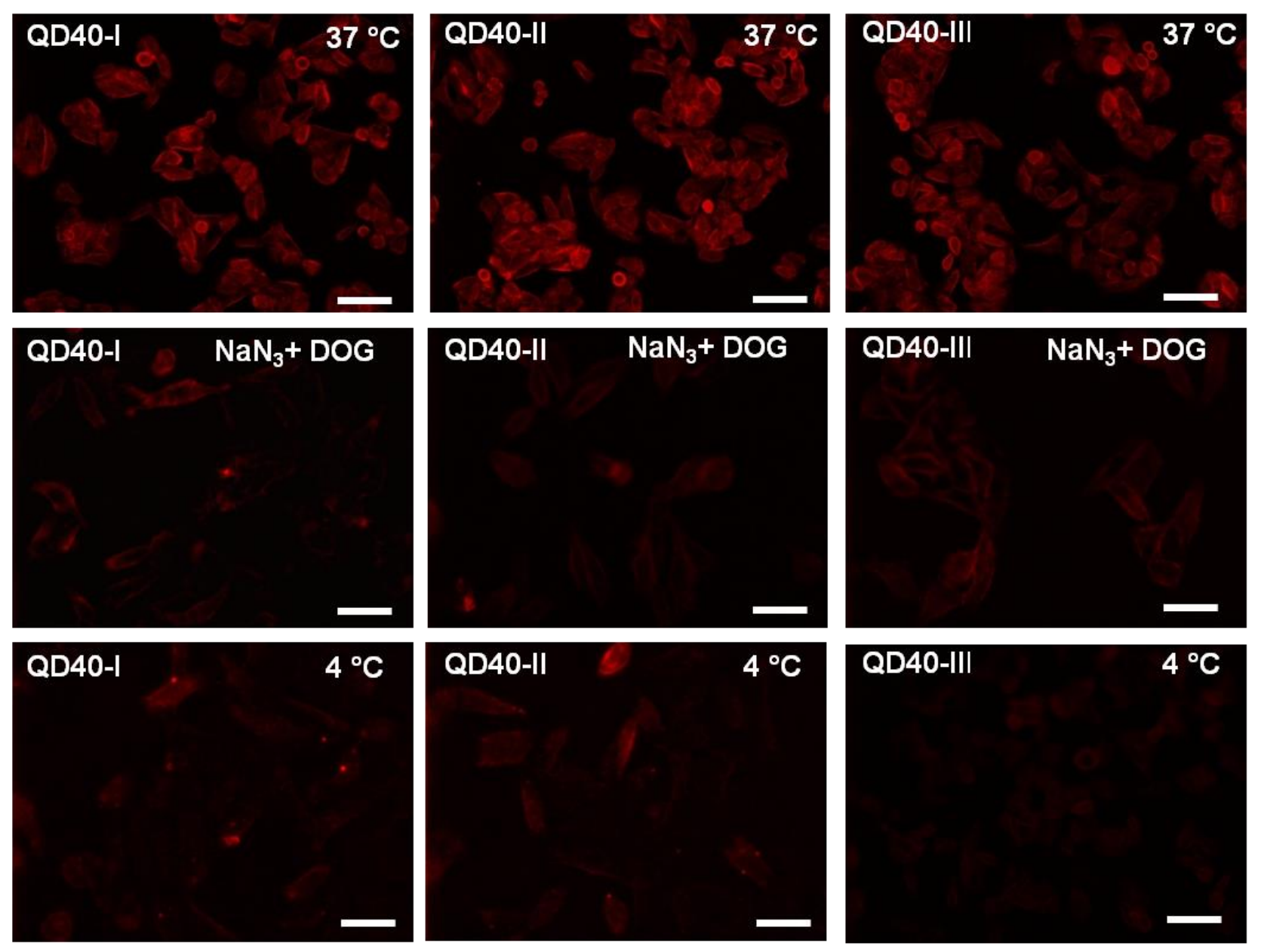

Figure S10. Fluorescence image of HeLa cells labelled with QD40-I, QD40-II and QD40-III at $37{ }^{\circ} \mathrm{C}, 4{ }^{\circ} \mathrm{C}, 37{ }^{\circ} \mathrm{C}$ in the presence of $\mathrm{NaN}_{3}$ and deoxy-glucose (DOG). Results show that QD uptake is significantly inhibited by $\mathrm{NaN}_{3}, \mathrm{DOG}$, or at $4{ }^{\circ} \mathrm{C}$, indicating their energy dependent uptake. Scale bar represents $50 \mu \mathrm{m}$. 

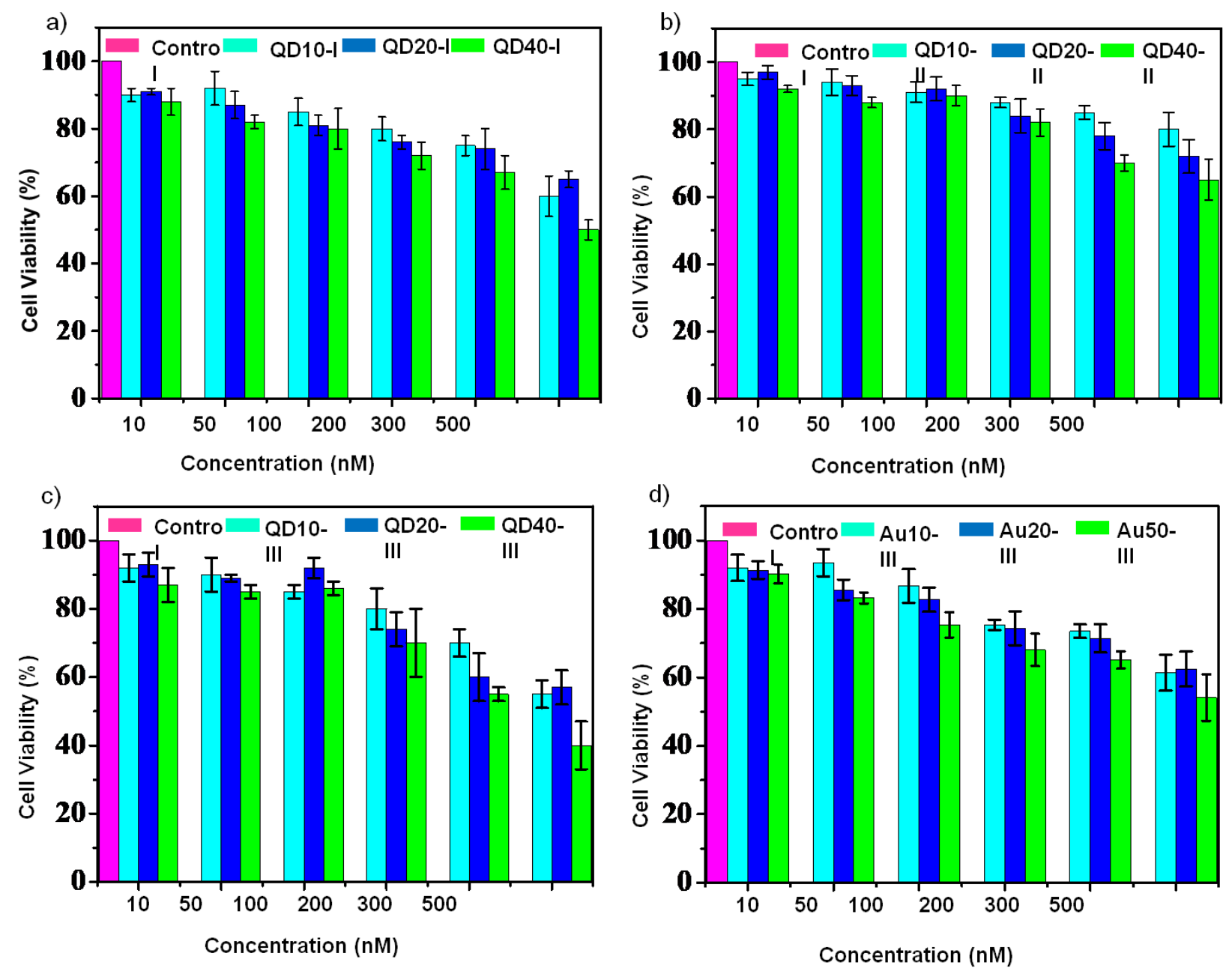

Figure S11. Cell viability study of HeLa cells with a) QD10-I, QD20-I, QD40-I b) QD10-II, QD20-II, QD40-II c) QD10-III, QD20-III, QD40-III and d) Au10-III, Au20-III, Au50-III.

Cells are incubated with nanoparticles for $24 \mathrm{~h}$ and cell viability is determined by taken 100 $\%$ viability for sample without any nanoparticle treatment. 